\title{
THE NECESSITY FOR INTEGRATION OF CRITICAL MEDIA LITERACY WITHIN ENGLISH FOR SPECIFIC PURPOSES (ESP) JOURNALISM
}

\author{
A. Sebryuk \\ National Research University Higher School of Economics \\ 20 Myasnitskaya st., Moscow, 101000, Russian Federation
}

Critical media literacy has gained much importance in Western educational curricula lately but still remains insufficiently explored and implemented in the English language education in Russian universities. This article explores the theoretical foundations of critical media literacy, discusses the necessity to focus on developing students' critical thinking skills with regard to the proper use of media in the context of English for journalism and provides examples of practical applications. Most English for Specific Purposes (ESP) courses that are designed for future journalists and specialists in media communications are focused solely on either theoretical knowledge about the profession or on general knowledge about the professional world and the language it uses, which is clearly not enough for a successful future activity.

The rapid development of the mass media causes a need for journalists of a new type: creative professionals, people who are able to access, analyze, evaluate, distribute media messages and act using all forms of communication. On the basis of the works of leading Russian and international researchers in the field of media education, the author offers a rationale for incorporating critical media literacy into the process of English language acquisition. Therefore, strategies that can be used to strengthen critical thinking abilities are given as well as an in depth analysis outlining the benefits of media literacy for journalism students.

Key words: critical media literacy, media education, ESP, journalism, English language teaching

\section{INTRODUCTION}

The use of media in English language classrooms has commonly been routinely recognized as a powerful tool for teaching. Although a wide range of education programs now include educational technology, there are indications that media literacy built on critical inquiry is not yet widespread.

Though mass culture is only about 150 years old, the true nature of its impact on society in general is just beginning to be studied. At present it appears to be insufficient to teach literacy that only addresses traditional concepts of media communication without taking into account the other principal ways we receive, process, and produce information and images. Many Russian language instructors assume that literacy is limited to reading and writing. While mass media have expanded notions of literacy and the ways people learn. Media literacy includes various skills in reading, writing, and speaking, using the computer, and decoding visual or even musical presentations of information.

This article addresses critical media literacy in Journalism ESP classrooms by applying a critical theoretical framework taken from teaching about media and English language 
teaching research. Since the global picture of reality is created by people working in the media, critical media literacy appears to be particularly important for preparing communication and mass media specialists. Due to the progress in communication technologies, a journalist in the 21st century needs to be multifaceted in their approach and must be able to use their foreign language skills to meet increasing requirements and to solve professional problems.

As the role of journalists in today's media-dominated age continues to evolve and as an educator I am focused on the pedagogical implications of helping students take advantage of modern media while simultaneously uncovering the codes and practices that work to silence and disempower them as readers, viewers, and learners in general.

The skills of thinking critically about mass media are essential survival skills in the 21 st century. Critical media literacy increases the proficiency of students to express their ideas in various print and nonprint media forms and it is this very skill that enables them to become sensible consumers of media and judicious creators of information.

\section{DISCUSSION}

In our research we are referring to the fundamental works focuses on media education through critical thinking.

The mass media, especially in the past century, have expanded notions of literacy and the ways people learn. It is precisely because of this that it is necessary to clarify exactly what is meant by media literacy. Luke (1999), for example, defines it as "teaching of analytic skills" [1. P. 623]. Thoman (1999) outlines: Media literacy is "the ability to create personal meaning from verbal and visual symbols we take in every day through television, radio, computers, newspapers and magazines, product-packaging, fashion, cosmetics, graffiti and, of course, advertising. It's the ability to choose and select, the ability to challenge and question, the ability to be conscious about what's going on around us-and not be passive and vulnerable" [2. P. 50].

According to Chamberlin-Quinlisk (2012), the professor of applied linguistics and communication arts and sciences, media literacy refers to the development of skills to use traditional and emerging media effectively, to the expanded use of multimodal literacies, and to the ability to decode media and understand the marketing strategies behind their messages [3].

Throughout this article, any reference to critical media literacy should be understood to fall within theoretical perspectives aimed at engaging students to critically analyze print and nonprint textual images, as well as the correlation between media and their customers, and information and power.

There is a considerable amount of literature on media education in Western Europe. Len Masterman (1997), one of the leading thinkers in the international media education movement, in the 1980s was the first to to propose the serious study of the mass media in schools. "Media Education is a lifelong process. Media Education aims to foster not simply critical intelligence, but critical autonomy" [4. Pp. 40-42].

According to the British documents (1999), teachers are obliged to use elements of media education in their classes, to consider how the meaning is embodied in an audiovisual 
image, how the purpose, form and representation affect the meaning and how the audience interacts with the media [5].

C. von Feilitzen (1999) claims that media education means critical thinking, which essential element is the creation by students of their own media production. Media education is critically important for active participation both in democracy and in globalization, and should be based on the study of all types of media [6. Pp. 24-26].

Leading international educators such as Alvermann and Hagood (2000), Hobbs (1998), and Thoman (1999) have recognized the need to address these new, changing literacies through critical media practices $[7 ; 8]$.

Many media educators openly express the belief that a media- literate student must be able to evaluate media texts critically and consciously, maintain a critical distance in relation to popular culture and resist manipulation. According to Worsnop (1999), media literacy is the ability to master, interpret/analyze and create media texts [9].

Media education is recommended to be implemented into national curriculum of all states, into the system of additional, informal and lifelong education» [10. Pp. 273-274].

In English-speaking countries, particularly in the United States, media literacy is taught both in integrated classes in the context of ordinary subjects (history, geography, English, etc.), as well as in independent courses (journalism, television, mass communication, film studies, etc.). It should be noted here that in the US the position of media education is becoming more and more stable especially in Language Arts (also known as English Language Arts), which are traditionally aimed at developing and improving the student's comprehension and capacity for use of the written and oral language. According to Wyatt (2010), the language classroom can become a place for public discussion and debate in which media images and stories are challenged [11].

In addition to traditional assignments, as a comparison of the original literary source and its adaptation, American teachers educate students on how to identify representation patterns of certain groups of people in different media texts (to recognize gender, ethnic and social stereotypes), analyze print and video advertising and identify the techniques which are used and the specifics of their choice. The class discusses the legal and ethical aspects of the reality show, learns to interpret films in terms of the social and moral attitudes and messages that they carry, analyze media stereotypes, caricatures in newspapers and magazines, political advertising and commercials, popular songs and even television shows [12].

With regards to foreign language acquisition and its correlation with critical media literacy, it is argued that even communicative language teaching, which emphasizes the use of language as a communication tool, does not really help students become proficient in the target language [13].

Hughes and Clandfield (2017), the authors in Macmillan, focus on the use of critical thinking in exercises, as well as the selection of appropriate material that could encourage the student to analyze the given facts, to apply an unconventional approach to solve various problems and to make the right choice [14].

Media education has been gaining much attention in Russia as well. National Pedagogical encyclopedia defines media education as a field in pedagogics that studies regular patterns and objective laws of media (newspapers, television, radio, cinema, etc.) [15]. To a greater or lesser extent, the experience of foreign media education was analyzed 
by a few Russian researchers: A. Sharikov, A. Fedorov, A. Novikova, N. Ryzhykh and others.

I. Lytvyn (2013), A. Sharikov, E. Cherkashin (1993), L. Zaznobina (1998) argue that a high level of media culture is essential for all people who are eager to take advantage of modern media to the full extent and to confront their negative influence at the same time [16-18].

By the notion media education we mean not only the ability to analyze and evaluate the information one receives from various media, but also "to transmit messages in a variety of forms" [19].

In Russia, the leaders in the field of media education are universities. In 2002 the educational and methodical department of the Ministry of Education of the Russian Federation registered the university specialization "media education". The need for the development of media competence is also specified in the Federal State Educational Standard of Higher Professional Education in the field of linguistics (Bachelor's Degree).

\section{How Does Critical Media Literacy Fit Into Journalism ESP Education?}

Journalism education implies a broad erudition of the student and his/her ability to analyze and synthesize information concerning a wide range of topics and issues.

Regrettably, insufficient attention has been paid to critical media literacy in the process of English language learning and teaching in Russia. As practice shows, acquiring professional competencies, the future journalist does not always have the ability to analyze and structure the information independently, check the facts and draw valid conclusions.

Given the lack of practical implementation of critical media literacy in ESP courses for journalists, it is vital that we introduce the basics of media literacy through the implementation of media technologies into the existing framework for English language education.

However, most often such ESP courses for future journalists and specialists in media communications are focused solely on either the theoretical knowledge about the profession or on the general knowledge about the professional world, which is clearly does not go far enough to guarantee the success of these aspiring professionals.

The rapid development of the mass media causes a need for journalists of a new type: well-rounded, creative professionals who are able to deal with situations of any complexity and capable of constant self-improvement.

While teaching English for journalism, the use of active forms of methods for searching and problem solving will promote cognitive activity and develop critical thinking. Media literacy can simultaneously sensitize students to methods of propaganda, challenge stereotypes in society, nurture a greater appreciation of the power of language, and promote reading, writing, and disciplined inquiry as well.

The process of turning a student into a professional journalist requires the integration of innovative teaching methods in the educational process. Instead of focusing on the fast-shifting content and knowledge of media, the main task of the English instructor is to make such educational environment that helps students develop their own professional skills and creative potential that they can then tap into and utilize from that day forward both in their professional and personal lives. 
The Internet contains a great amount of public educational resources, presented in audio, video and text formats. Teachers actively use Internet services such as social networks, blogs, webinars, forums, which help to improve and raise the intellectual level of students. The rapid increase in the information flow requires the ability to navigate in it. Consequently, the formation of critical thinking is now becoming particularly relevant.

Critical thinking allows students to achieve such educational results as the ability to work with an increasing and constantly updated information flow in different fields of knowledge; express their thoughts, develop their own opinions and solve problems; The ability to learn on their own; Cooperate and build efficient relationships with other people.

The main purpose of the English course is to teach practical knowledge of journalism English and the ability to use English both in professional and everyday communication.

Traditionally, the ESP course for journalists sets the following aims:

- expanding vocabulary;

- developing reading skills;

- developing grammar skills;

— developing communicating skills;

- developing translation skills;

— developing skills of professional writing.

It can be observed that there is still considerable ambiguity concerning critical media literacy. The main limitation of the courses is that they do not tend to focus on strengthening critical thinking skills with regards to media literacy. This significant downside may lead to the inability of future mass media professionals to become active participants in a rapidly changing media landscape.

While teaching English to future journalists I am focused on the following aims: to prepare students to life in the modern world of information, to help them learn how to perceive different information, to analyze it and to realize the impact that it has on human psyche. Students are encouraged to analyze the given facts, to apply an unconventional approach to solve various problems and to make the best choice of what to do with that information going forward utilizing those intellectual tools that I have equipped them with.

\section{Examples of practical applications}

In essence, to develop students' critical thinking among journalism students I support and empower students to analyze media, solve problems or moral dilemmas and practice debating in English.

Here are a number of suggestions of classroom exercises which enhance critical thinking among language students stimulating their creativity and self-expression.

1. Discussing news or a magazine article from various sources or/and countries to examine opposite points of view, common points of view, the language used, etc. Students from other cultures can contrast what they see in the foreign media with the knowledge of their own cultures and global stereotypes existing in their society. Asking the students if they see examples of bias, either in the piece itself or in the language chosen.

2. Analyzing advertisements and commercials, political cartoons and social media.

3. Investigating such social constructions as race, gender, ability, age, and examining how these constructions are established in society. 
4. Creating an advertisement or a short film to express a message.

5. Writing articles and reviews to convey a concept, express an idea/opinion and to persuade an audience.

6. Creating a blog or any media piece to share thoughts and points of view. The students may take another identity with a different gender, different nationality, and different age.

7. Rewriting scenes for television programs, or writing prequels or sequels, to enable students to offer different representations of the story or/and characters.

The activities suggested here are just a few among many assignments which if used in class can help students think critically. The instructor can choose the most appropriate ways of language assessment with regard to the main objectives of the class.

While practicing the material and improving spontaneous speech, students develop their emotional intelligence by exercising empathy and social connections. These discussions help them see the world from a different angle and enhance the feeling of personal responsibility.

As an instructor, I prefer to follow certain rules in performing a dilemma discussion/ problem solving in class.

1. A scenario of a dilemma is based on some value or moral issue.

2. A group of people or one person is in the center of the dilemma.

3. Students must suggest an idea or give advice for the character and justify their choice.

The discussion can be facilitated by these questions:

- What might you do in these situations?

- What are the pros and cons to the various options?

- Are there any negative consequences to your chosen actions? What might you do to minimize them?

- Is there any way you could have prevented these situations from arising in the first place?

Another activity that strengthens critical thinking abilities and requires all English language skills along with the skills of presentation and delivery is debating.

A debate is meant to be a a rhetoric practice in which two separate groups give speeches to support their views and disagree with the members from the other group. According to Krieger (2005), it makes students involved in a wide range of cognitive and linguistic ways [20]. This practice encourages students to think about the multiple sides of a topic, to use the language in the form of expressing their views with logic and to interact with each other. It is advisable that students are allowed to make their own decisions rather than having the instructor assign sides to the debate.

In the context of critical media literacy the instructor contributes the activity with some listening aids, for example video clips, podcasts, talk shows and news. If debating is practiced appropriately, along with critical media literacy students will improve both their English language and presentation skills which are essential in personal, academic and professional environments.

\section{CONCLUSION}

Summing it up, it is absolutely vital that critical media literacy is fostered among language learners due to its significance in developing effective language acquisition. It increases the proficiency of students to communicate their thoughts in a wide range of 
print and nonprint media forms and it enables them to become sensible consumers of media and responsible producers of information.

As educators and researchers, we need to integrate opportunities to develop media literacies into lessons, curricula, and programs in order to foster a better language learning and practice. Implementing critical media literacy in the English classroom provides students with the opportunity to envisage real-life context and authentic language use. Moreover, the experience students accumulate from the class is universal and may be applied in all subject areas as well as in various spheres of life.

Unquestionably, a critical media literacy perspective can bring one's teaching to a significantly new level. Standards for the integration of critical media literacy in the study of English should include analyzing and criticizing the ways that media reproduce racism, xenophobia, sexism and other prejudices and biases while encouraging students to find their own voices in media culture and creating alternative representations. I encourage other English language instructors to consider the systematic integration of critical media literacy to advance not only the development of professionals in a particular field but also for the development of socially active citizens and analytical thinkers.

(C) Sebryuk A.N., 2017

\section{REFERENCES}

1. Luke C. Media and cultural studies in Australia. Journal of Adolescent \& Adult Literacy. 1999. 42(8). Pp. 622-626.

2. Thoman E. Skills and strategies for media education. Educational Leadership. 1999. 56 (5). Pp. 50_ 54.

3. Chamberlin-Quinlisk C. TESOL and Media Education: Navigating Our Screen-Saturated Worlds. TESOL Quarterly. Vol. 46. No. 1 (March 2012). Pp. 152-164.

4. Masterman L. A Rational for Media Education. In: Media Literacy in the Information Age. New Brunswick (U.S.A.) and London (U.K.): Transaction Publishers. 1997. Pp. 40-42.

5. The National Curriculum. Qualifications and Curriculum Authority. URL: http://www. educationengland.org.uk/documents/pdfs/1999-nc-primary-handbook.pdf (accessed 25 April 2017).

6. von Feilitzen C. Media education, children's participation and democracy. In C. von Feilitzen and U. Carisson (Eds.). Children and media: Image, education and participation (pp. 15-30). Goteborg, Sweden: The UNESCO International Clearinghouse on Children and Violence on the Screen, 1999.

7. Alvermann D., Hagood M. Critical Media Literacy: Research, Theory, and Practice in 'New Times'. Journal of Educational Research 93, 2000. Pp. 193-205.

8. Hobbs R. The seven great debates in the media literacy movement. Journal of communication. 1998. 48(1). Pp. 16-32.

9. Worsnop C. Screening Images: Ideas for Media Education.Second Edition. Mississauga: Wright Communication, 1999.

10. Recommendations Addressed to the United Nations Educational Scientific and Cultural Organization UNESCO. In: Education for the Media and the Digital Age. Vienna: UNESCO. Pp. 273-274. Reprint in: Outlooks on Children and Media. Goteborg: UNESCO \& Nordicom, 2001. P. 152.

11. Wyatt W. The ethical responsibilities of news consumers. In C. Meyers (Ed.). A Philosophical Approach to Journalism Ethics. New York: Oxford University Press, 2010. Pp. 283-95.

12. Fedorov A., Novikova A., Kolesnichenko V., Karuna I. Media Education in the USA, Canada and Great Britain. Taganrog, 2007. 256 p. 
13. Stanley G. Language Learning with Technology: Ideas for integrating technology in the classroom. Cambridge Handbooks for Language Teachers. Ed. Scott Thornbury. Cambridge: Cambridge UP, 2013.

14. Hughes J., Clandfield L. ETpedia Materials Writing Pavilion Publishing, 2017.

15. National Pedagogical encyclopedia. URL: http://didacts.ru (accessed 25 April 2017).

16. Lytvyn N.O. Profession oriented media psychology in media training of future editors. Media education. 2013. Pp. 294-303.

17. Zaznobina L. Media Education Standard Integrated Across the Curriculum. Standards and Monitoring in Education. 1998. 3. Pp. 26-34.

18. Sharikov A., Cherkashin E. Experimental Curricula for Media Education. Moscow: Russian Pedagogical Academy, 1993.

19. Fedorov A.V. Media Education Dictionary: Media Education, Media Literacy, Media Studies, Media Competence. Moscow: ICO "Information for All, 2014. 64 p.

20. Krieger D. Teaching Debate to ESL Students: A Six-Class Unit The Internet TESL Journal, 2005. URL: http://iteslj.org/Techniques/Krieger-Debate.html (accessed 25 April 2017).

Article history:

Received: 09.08.2017

Accepted: 23.09.2017

Moderator: O.A. Valikova

Conflict of interests: none

For citation:

Sebryuk A.N. (2017). The Necessity for Integration of Critical Media Literacy within English for Specific Purposes (ESP) Journalism. RUDN Journal of Language Education and Translingual Practices, 14 (4), 694-702. DOI 10.22363/2312-8011-2017-14-4-694-702

\title{
Bio Note:
}

Sebryuk Anna Nabievna is a Candidate in Philology, Docent of the Chair of English at the Department of Foreign Languages of National Research University Higher School of Economics. E-mail: sebryuk.anna@gmail.com

\section{НЕОБХОДИМОСТЬ ИНТЕГРАЦИИ КРИТИЧЕСКОЙ МЕДИАГРАМОТНОСТИ В КУРС АНГЛИЙСКОГО ЯЗЫКА ДЛЯ ЖУРНАЛИСТОВ}

\author{
А.Н. Себрюк \\ Национальный исследовательский университет Высшая школа экономики \\ Российская Федерация, 101000, Москва, ул. Мясницкая, д. 20
}

Критическая медиаграмотность, уже став важнейшим компонентом в западноевропейской системе образования, все еще остается недостаточно освещенной и применяемой в обучении английскому языку в российских университетах. В статье рассматривается теория критической медиаграмотности, обсуждается необходимость акцентировать внимание на развитии крити- 
ческого мышления студентов применительно к средствам массовой информации в контексте обучения английскому языку будущих журналистов, а также приводятся примеры практических заданий. Большинство курсов английского языка для журналистов и специалистов медиакоммуникаций сосредоточено на теоретических знаниях о профессии или на общем понимании профессионального мира и языка, который в нем используется, что является недостаточным для успешной карьеры в данной деятельности.

Быстрое развитие средств массовой коммуникации обусловливает спрос на журналистов нового типа - креативных профессионалов, которые обладают независимостью суждений и умением анализировать, грамотно оценивать и создавать сообщения в разных видах, жанрах и формах медиа. На основании теоретических и научно-методических работ российских и зарубежных исследователей в области медиаобразования автор дает логическое обоснование для включения критической медиаграмотности в процесс обучения английскому языку. В связи с этим предлагаются стратегии для развития навыков критического мышления; приводятся новые способы вовлечь студентов в учебный процесс и побудить их к критическому анализу медиаконтента. Выводом работы ставится предположение о необходимости совершенствования медиаграмотности для студентов факультета журналистики в рамках курса английского языка для специальных целей.

Ключевые слова: критическая медиаграмотность, медиаобразование, английский язык для специальных целей, журналистика, обучение английскому языку

\section{История статьи:}

Поступила в редакцию: 09.08.2017

Принята к публикации: 23.09.2017

Модератор: О.А. Валикова

Конфликт интересов: отсутствует

\section{Для цитирования:}

Себрюк А.Н. Необходимость интеграции критической медиаграмотности в курс английского языка для журналистов // Вестник Российского университета дружбы народов. Серия: Вопросы образования: языки и спещиальность. 2017. Т. 14. № 4. С. 694-702. DOI 10.22363/23128011-2017-14-4-694-702

Сведения об авторе:

Себрюк Анна Набиевна - кандидат филологических наук, доцент кафедры английского языка для гуманитарных дисциплин Департамента иностранных языков НИУ ВШЭ. E-mail: sebryuk.anna@gmail.com 